\title{
Penyalahgunaan Keadaan dalam Perjanjian Pinjam Meminjam Uang oleh Rentenir
}

\author{
Ahmad Arif Syarif \\ ahmad_arif@live.com
}

\begin{abstract}
This study examines, first, what are the benchmarks used by court in determining the misuse of circumstance in loan agreements by loan sharks? Second, what are the legal consequences of loan agreements that contain elements of circumstance misuse? This study is library research with a normative juridical approach to observe the phenomenon of loan sharks from a legal perspective. The results indicate that, first, there are three benchmarks used by court in determining the misuse of circumstance loan agreements, including moral benchmark of fairness and propriety, benchmark of good faith, and benchmark of profit. Secondly, the legal consequences of loan agreements by loan sharks can be void if one of the aggrieved parties requests cancellation before the judge due to misuse of circumstance. This reason is then classified into the fourth defect of will apart from the other three defects of will that have been regulated in the Civil Code.
\end{abstract}

Keywords: Loan agreements, misuse of circumstances

\begin{abstract}
Abstrak
Studi ini mengkaji tentang: pertama, bagaimana tolok ukur yang digunakan pengadilan dalam menentukan adanya penyalahgunaan keadaan dalam perjanjian pinjam meminjam uang oleh rentenir? Kedua, akibat hukum dari perjanjian pinjam meminjam uang yang mengandung unsur penyalahgunaan keadaan? Penelitian termasuk dalam jenis penelitian pustaka dengan sifat penelitian normatif yang menggunakan pendekatan yuridis normatif, yaitu melihat fenomena rentenir ini dari segi hukum. Hasil penelitian ini menunjukkan, pertama, terdapat tiga tolok ukur yang digunakan oleh pengadilan dalam menentukan adanya penyalahgunaan keadaan dalam perjanjian pinjam meminjam uang dari putusan-putusan tersebut, yaitu tolok ukur moral yang meliputi keadilan dan kepatutan, tolok ukur itikad baik, dan tolok ukur keuntungan. Kedua, akibat hukum dari perjanjian pinjam meminjam uang oleh rentenir adalah dapat dibatalkan jika salah satu pihak yang dirugikan memohon pembatalan di hadapan hakim karena alasan adanya penyalahgunaan keadaan. Alasan ini kemudian digolongkan ke dalam cacat kehendak yang ke empat di luar dari tiga cacat kehendak yang telah diatur dalam KUHPerdata.
\end{abstract}

Kata Kunci: Perjanjian Pinjam Meminjam, Penyalahgunaan Keadaan. 


\section{Pendahuluan}

Salah satu fenomena yang masih hidup dan masih eksis di masyarakat adalah rentenir, yaitu seseorang yang melakukan kegiatan peminjaman uang atau modal. Renten atau kegiatan renten merupakan suatu aktifitas dimana seseorang meminjamkan uang dengan bunga yang berlipat-lipat yang memungkinkan bunga tersebut melebihi utang pokoknya jika cicilannya terlambat. ${ }^{1}$ Eksistensi praktik rentenir ini dikarenakan masyarakat menyadari lebih mudahnya dan lebih efisiennya meminjam uang dari rentenir dari pada meminjam uang dari bank atau lembaga peminjaman lainnya. Sebab apabila masyarakat meminjam uang dari rentenir tidak membutuhkan kelengkapan surat-surat identitas dan keterangan jenis usaha lainnya, selain prosesnya juga cepat masyarakat juga diberi kemudahan untuk mencicil atau mengangsur uang peminjaman tersebut perhari, perminggu, bahkan perbulan. ${ }^{2}$ Sesuai dengan kemampuan dan kesepakatan yang telah disepakati antara peminjam dan si rentenir. Selain itu tidak ada hukum peradilan yang melarang pekerjaan tersebut.

Namun demikian, keberadaan rentenir atau pelepas uang (money lender) di Indonesia sulit terdeteksi pihak luar (outsiders) karena cenderung bersifat tertutup. Kondisi tersebut dikarenakan dalam kehidupan masyarakat luas di Indonesia, pekerjaan sebagai rentenir dipandang sebagai pekerjaan yang negatif. Jika ditarik dari sudut pandang agama dan norma masyarakat, rentenir adalah pekerjaan yang tidak dapat dibenarkan. ${ }^{3}$

Rentenir biasanya beroperasi di saat panen gagal, ketika para petani sangat membutuhkan uang namun tidak dapat memberi jaminan kepada bank dan juga para pedagang kecil yang membutuhkan modal usaha. Sasaran rentenir lainnya adalah konsumen produk perbankan yang telah dimasukkan ke daftar hitam karena bermasalah dengan bank (kredit macet). Atau pengusaha-pengusaha kecil

\footnotetext{
${ }^{1}$ Ilas Korwadi Siboro, "Rentenir (Analisis terhadap Fungsi Pinjaman Berbunga dalam Masyarakat Rokan Hilir Kecamatan Bagan Sinembah Desa Bagan Batu)", Jom Fisip, Edisi No. Vol. 2, 2015, hlm. 1

${ }^{2}$ Delmira Syafrini, "Nelayan vs Rentenir Studi Ketergantungan Nelayan terhadap Rentenir pada Masyarakat Pesisir, Jurnal Ilmu Sosial Mamangan, Edisi No. 2, Vol. I. 2014.

3 Aldrin Ali Hamka dan Tyas Danarti, "Eksistensi Bank Thithil dalam Kegiatan Pasar Tradisional (Studi Kasus di Pasar Kota Batu)," Journal of Indonesian Applied Economics, Edisi 1 Vol. 4. 2010, hlm. 58
} 
menengah yang kesulitan akses permodalan dari bank serta rumah tangga-rumah tangga yang memerlukan dana cepat. Pinjaman dari rentenir atau tengkulak tidak memerlukan jaminan sertifikat rumah atau barang berharga lainnya (kebanyakan hanya memerlukan kartu tanda penduduk atau identitas lainnya), namun memiliki risiko tinggi. ${ }^{4}$

Seperti pada perjanjian pada umumnya, perjanjian pinjam meminjam meminjam uang oleh rentenir ini tentu melibatkan dua belah pihak, yaitu pihak yang memberikan pinjaman (kreditor) dan pihak yang menerima pinjaman (debitor). Kedua belah pihak ini mengadakan sebuah perjanjian atau kesepakatan pinjam meminjam uang yang disertai dengan bunga yang sudah ditentukan oleh kreditor. Dalam pembentukan kesepakatan melalui pernyataan kehendak ini, terkadang posisi tawar antara kedua belah pihak tidak seimbang, debitor dalam kondisi terdesak dan sangat membutuhkan uang menempati posisi tawar yang lemah sementara kreditor yang memiliki uang (keunggulan secara ekonomi) dengan posisi tawar yang lebih kuat menetukan bunga yang cukup besar. Dalam kondisi demikian pembentukan kata sepakat melalui perjumpaan kehendak kedua belah pihak menjadi cacat.

Cacat kehendak atau cacat kesepakatan dapat terjadi karena kekhilafan atau kesesatan, paksaan, penipuan, dan penyalahgunaan keadaan. ${ }^{5}$ Tiga cacat kehendak yang pertama diatur dalam KUHPerdata sedangkan cacat kehendak yang terakhir (penyalahgunaan keadaan) tidak diatur dalam KUHPerdata, namun lahir kemudian dari yurisprudensi. Penyalahgunaan keadaan berkaitan dengan kondisi yang ada pada saat kesepakatan terjadi, yang membuat satu di antara dua pihak berada dalam keadaaan tidak bebas untuk menyatakan kehendaknya. Seorang rentenir seperti contoh kasus di atas dalam posisinya yang memiliki banyak dana (keunggulan ekonomi) memanfaatkan kondisi dirinya untuk memberi pinjaman dengan bunga sesukanya dan dalam jangka waktu sesukanya juga bahkan terkadang hampir tidak masuk akal, dan di posisi yang lemah seorang peminjam dengan kondisinya yang mendesak karena tidak ada pilihan lain.

\footnotetext{
${ }^{4}$ Sirait, Lisken, "Fenomena Rentenir di Pasar Bintan Center (Studi Pedagang Kecil di Pasar Intan Center)," Skripsi, Universitas Maritim Raja Ali Haji FISIPOL, Tanjungpinang, 2015.

${ }^{5}$ Fani Martiawan Kumara Putra, "Paksaan Ekonomi dan Penyalahgunaan Keadaan sebagai Bentuk Cacat Kehendak dalam Perkembangan Hukum Kontrak”, Jurnal Yuridika, Vol. 30 No. 2, Mei-Agustus 2015, hlm. 238
} 
Penyalahgunaan keadaan sebagai salah satu doktrin yurisprudensi dalam hukum perdata menjadi menarik untuk dikaji perkembangan zaman yang selalu dinamis sehingga model kontrak juga akan selalu berkembang. Pengadilan sebagai salah satu lembaga penegak hukum perlu lebih jauh mengaplikasikan doktrin ini menuju arah pembangunan hukum yang positif. Hukum sudah seyogyanya mengakomodir segala kepentingan masyarakat untuk menciptakan konstruksi atau bangunan sosial yang adil sesuai cita-cita negara.

Menurut Satjipto Rahardjo, hakim dalam memutuskan perkara perlu menggali nilai-nilai yang ada dalam kehidupan masyarakat, maka akan lebih dapat memberikan rasa keadilan bagi masyarakat karena pada prinsipnya hukum adalah untuk manusia bukan sebaliknya manusia untuk hukum. Dengan demikian ketika masyarakat berubah, maka hakim dalam penegakan hukum juga harus mengikuti perkembangan yang terjadi dalam dinamika kehidupan masyarakat. Pengadilan bukanlah institusi hukum yang steril yang hanya berurusan dengan pengkonkretan undang-undang, melainkan memiliki jangkauan yang lebih luas. Pengadilan sudah menjadi institusi sosial yang peka terhadap dinamika perkembangan masyarakat. Pengadilan sarat dengan pikiran keadilan, pembelaan rakyat dan nasib bangsanya. Ternyata pengadilan juga berhati nurani (concience of the court). Hakim sebagai penegak hukum di pengadilan harus benar-benar memerhatikan dinamika masyarakat. Hakim berhati nurani dalam memutus perkara, sehingga benar-benar bisa memberikan keadilan bagi masyarakat. ${ }^{6}$

Studi penelitian ini mengkaji aspek penyalahgunaan keadaan dalam perjanjian pinjam meminjam uang yang dilakukan oleh rentenir, lebih khusus membahas pada indikasi yang digunakan oleh pengadilan dalam menentukan penyalahgunaan keadaan serta akibat hukum dalam perjanjian pinjam meminjam uang tersebut. Terdapat beberapa hal yang mendasari perlunya penelitian ini diadakan. Pertama, bahwa perilaku rentenir masih banyak hidup di masyarakat yang sedikit banyak tentu akan merugikan pihak yang meminjam dalam kondisi-

${ }^{6}$ Siti Malikhatun Badriyah, Sistem Penemuan Hukum dalam Masyarakat Prismatik, Sinar Grafika, Jakarta, 2016, hlm. 48. 
kondisi tertentu. Hukum (khususnya hukum kontrak) yang dicorongkan oleh hakim harus lebih jeli melihat kasus ini untuk diberikan jalan keluar. Kedua, konsep penyalahgunaan keadaan ini masih belum sempurna dalam tatanan hukum Indonesia meskipun berangkat dari yurisprudensi dan doktrin dari common law, namun perlu kiranya melihat aplikasi konsep penyalahgunaan keadaan terhadap perjanjian pinjam meminjam uang ini.

Berangkat dari pemaparan di atas, ada dua fokus masalah yang dikaji dalam penelitian ini yaitu tentang tolok ukur yang digunakan pengadilan untuk menentukan adanya penyalahgunaan keadaan dalam perjanjian pinjam meminjam uang dan akibat hukum dari perjanjian pinjam meminjam uang oleh rentenir yang mengandung unsur penyalahgunaan keadaan.

\section{Rumusan Masalah}

Berdasarkan uraian latar belakang di atas, maka penelitian ini mengajukan rumusan masalah, pertama, bagaimana tolak ukur yang digunakan pengadilan untuk menentukan adanya penyalahgunaan keadaan dalam perjanjian pinjam meminjam uang? Kedua, bagaimana akibat hukum dari perjanjian pinjam meminjam uang yang mengandung unsur penyalahgunaan keadaan?

\section{Tujuan Penelitian}

Pertama, untuk menganalisis dan mengetahui tolak ukur yang digunakan pengadilan untuk menentukan adanya penyalahgunaan keadaan dalam perjanjian pinjam meminjam uang. Kedua, untuk menganalisis dan mengetahui akibat hukum dari perjanjian pinjam meminjam uang yang mengandung unsur penyalahgunaan keadaan.

\section{Metode Penelitian}

Penelitian ini termasuk ke dalam jenis penelitian pustaka, yaitu mengkaji penyalahagunaan keadaan dalam perjanjian pinjam meminjam uang oleh rentenir dengan menelusuri beberapa literatur pustaka yang berkaitan dengan pembahasan tersebut. Pendekatan yang digunakan dalam penelitian ini yaitu pendekatan normatif yuridis, pendekatan normatif yaitu melihat fenomena rentenir dari aspek 
norma dan pendekatan yuridis yaitu mengkaji fenomena perjanjian pinjam meminjam uang oleh rentenir ini dari tinjauan hukum yang berlaku.

Bahan hukum yang digunakan dalam penelitian ini ada dua, yaitu bahan hukum primer dan bahan hukum skunder. Bahan hukum primer meliputi undangundang, peraturan hukum lainnya yang memiliki kekuatan hukum yang berkaitan dengan pembahasan, termasuk di dalamnya tiga putusan yang dikaji untuk membahas doktrin tentang penyalahgunaan keadaan. Tiga putusan tersebut yaitu putusan Pengadilan Negeri Wonogiri 04/Pdt G/2014/PN.Wng, putusan Pengadilan Negeri Jakarta Pusat No. 425/Pdt.G/2011/PN.JKT.PST dan Putusan Mahkamah Agung No. 2054 K/Pdt/2014. Adapun bahan hukum sekunder meliputi buku atau karyah ilmiah lainnya yang menjelaskan tentang apa yang menjadi bahan hukum primer tersebut di atas.

Data yang dikumpulkan dari studi kepustakaan dianalisis dengan menggunakan teknik kualitatif, dengan menggunakan dua tahap analisis, pertama analisis domain, yaitu analisis atau potret yang bersifat umum tentang Hukum Perjanjian meliputi syarat-syarat sah dan asas-asas umum serta potret tentang perjanjian yang dilakukan oleh rentenir dengan nasabahnya. Kedua analisis taksonomi, yaitu analisis yang lebih fokus pada indikasi yang dipakai pengadilan dalam menetukan penyalahgunaan keadaan yang terjadi pada perjanjian pinjam meminjam uang oleh rentenir serta akibat hukum dari perjanjian yang terdapat unsur penyalahgunaan keadaan tersebut.

\section{Hasil Penelitian dan Pembahasan}

Keabsahan suatu perjanjian merupakan hal terpenting dalam mencapai kepastian dan perlindungan hukum bagi para pihak, oleh karena itu perjanjian yang dilakukan oleh dua belah pihak atau lebih harus tersebut memenuhi beberapa syarat yang sudah diatur dalam Pasal 1320 KUHPerdata: 1) Sepakat mereka yang mengikatkan dirinya; 2) Kecakapan untuk membuat suatu perikatan; 3) Suatu hal tertentu; 4) Suatu sebab yang halal.

Pasal 1320 KUHPerdata ini, merupakan pasal yang sangat populer karena menerangkan tentang syarat yang harus dipenuhi untuk lahirnya suatu perjanjian. 
Syarat tersebut baik mengenai pihak yang membuat perjanjian atau biasa disebut syarat subjektif maupun syarat mengenai perjanjian itu sendiri (isi perjanjian) atau yang biasa disebut syarat objektif. ${ }^{7}$

Unsur subjektif mencakup adanya unsur kesepakatan secara bebas dari para pihak yang berjanji, dan kecakapan dari pihak-pihak yang melaksanakan perjanjian. Sedangkan unsur objektif meliputi keberadaan dari dari pokok persoaln objek yang diperjanjikan, dan causa dari objek yang berupa prestasi yang disepakati untuk dilaksanakan tersebut haruslah sesuatu yang tidak dilarang atau diperkenankan menurut hukum. Tidak terpenuhinya salah satu unsur dari keempat unsur tersebut menyebabkan cacat dalam perjanjian, dan perjanjian tersebut diancam dengan kebatalan, baik dalam bentuk dapat dibatalkan (jika terdapat pelanggaran terhadap unsur subjektif), maupun batal demi hukum (dalam hal tidak terpenuhinya unsur objektif), dengan pengertian bahwa perikatan yang lahir dari perjanjian tersebut tidak dapat dipaksakan pelaksanaannya. ${ }^{8}$

Terbentuknya kesepakatan dalam sebuah perjanjian menjadi sangat penting karena hal ini merupakan ruh dari perjanjian, oleh karenanya dalam mewujudkan pembentukan kata sepakat diperlukan tindakan hukum dari kedua belah pihak yaitu dengan pernyataan kehendak. Namun, dalam praktiknya, seringkali kesepakatan itu merupakan hasil dari paksaan, penipuan, kekeliruan, atau penyalahgunaan keadaan. Kesepakatan yang terjadi karena adanya salah satu unsur tersebut disebut dengan kesepakatan yang mengandung cacat kehendak. ${ }^{9}$

Cacat kehendak dalam (wilsgebreke) dalam kesepakatan terjadi jika terdapat keadaan yang tidak normal, dalam arti terdapat unsur-unsur kekeliruan/kesesatan (dwaling), kekerasan/paksaan (berdreiging, dwang), dan penipuan (bedrog) dalam proses terjadinya kesepakatan yang dilakukan oleh satu atau lebih pihak yang membuat kontrak sebagaimana diatur dalam Pasal 1322 sampai dengan Pasal 1328 KUHPerdata. Selain itu, juga terdapat unsur penyalahgunaan keadaan (misbruik

${ }^{7}$ Ahmadi Miru, Sakka Pati, Hukum Perikatan Penjelasan Makna Pasal 1233 sampai 1456 BW, Rajawali Press, Jakarta, 2011, hlm. 3.

${ }^{8}$ Kartini Muljadi, Gunawan Widjaja, Perikatan yang Labir dari Perjanjian, Rajawali Press, Jakarta, 2014, hlm. 94.

9 Ridwan Kharandy, Hukum Kontrak Indonesia dalam Perspektif Perbandingan (Bagian Pertama), FH UII Press, Yogyakarta, 2014, hlm. 217. 
van omstandigheden) yang belum diatur secara normatif dalam KUHPerdata, tetapi berkembang dalam doktrin hukum dan yurisprudensi. ${ }^{10}$

Sebagai doktrin yang sudah lama berkembang, penerapan penyalahgunaan keadaan sudah banyak ditemukan dalam beberapa putusan pengadilan, khususnya dalam beberapa perkara tentang perjanjian. Penerapan doktrin penyalahgunaan oleh hakim merupakan bentuk kemajuan pengadilan untuk memberikan rasa keadilan yang penuh bagi masyarakat khususnya masyarakat kecil.

Penerapan doktrin penyalahgunaan keadaan ini dapat ditemukan dalam beberapa kasus perjanjian, salah satunya dalam perjanjian pinjam meminjam uang sebagaimana yang dibahas dalam penelitian ini. Di antara putusan-putusan tersebut adalah:

\section{Putusan Pengadilan Negeri Wonogiri}

Perkara yang ditangani oleh pengadilan Negeri Wonogiri (No. Perkara 04 / Pdt G/2014/PN.Wng) antara Yustinus Soeroso selaku Penggugat dengan H. Soeratno dan Hj. Soelityaningsih selaku Tergugat. Awal mula kasus ini pada 11 Juni 2012 antara Penggugat dengan Tergugat yang telah bersepakat untuk melakukan jual beli tiga bidang tanah milik para tergugat, yaitu 2 bidang tanah dengan sertifikat hak milik atas nama Soeratno dan 1 bidang tanah dengan sertifikat hak milik atas nama Soelistyaningsih, yang tertuang dalam Akta Notaris Arif Budiyanto, SH Nomor 60, 11 Juni 2012 tentang perjanjian ikatan jual beli.

Dalam Pasal 2 akta perjanjian ikatan jual beli tersebut ditentukan harga 3 bidang tanah sebanyak Rp. 12.500.000.000,- yang kemudian dibayar oleh penggugat secara bertahap selama 2 kali dengan perincian tanda jadi sebesar Rp. 5.500.000.000sebagai uang muka yang telah dibayar pada saat ditandatanganinya akta tersebut. Pembayaran tahap kedua sebesar Rp. 7.000.000.000,- akan dibayar paling lambat 11 Juni 2013. Kemudian pada tanggal yang ditentukan yaitu 11 Juni 2013 penggugat menghadap kepada notaris/PPAT yang ditunjuk untuk melunasi pembayaran tahap kedua tersebut namun menurut penggugat para tergugat

10 Muhammad Syaifuddin, Hukum Kontrak Memahami Kontrak dalam Perspektif Filsafat, Teori, Dogmatik dan Praktik Hukum (Seri Pengayaan Hukum Perikatan), CV Mandar Maju, Bandung, 2012, hlm 117. 
berkelit dan tidak mau hadir di hadapan notaris/PPAT Arif Budiyanto, sehingga dilakukan panggilan kembali kepada para tergugat sampai dengan tiga kali panggilan, namun tetap menolak tanpa alasan hukum yang sah. Sehingga penggugat melayangkan gugatan kepada pengadilan setempat yang berwenang atas kasus wanprestasi dalam perjanjian jual dengan tergugat.

Melalui gugatan tersebut, para tergugat membantah tentang perjanjian ikatan jual beli tersebut dengan alasan bahwa sebenarnya yang terjadi adalah tergugat meminjam uang kepada penggugat pada tanggal 11 Juni 2012 sebesar Rp. 5.000.000.000,- untuk pokok hutang dan Rp. 500.000.000,- untuk jasa / bunga, dalam jangka waktu satu tahun, sehingga ketika jatuh tempo pada 11 Juni 2013 dikembalikan Rp. 5.500.000.000,-. Perjanjian ikatan jual beli tersebut adalah perjanjian yang tidak berdiri sendiri namun diawali dengan perjanjian hutang piutang yang kemudian berlaku jika tergugat tidak mau melunasi hutangnya kepada penggugat. Adapun kesepakatan jasa dari hutang piutang sebesar 10\% per tahun tersebut memang ada namun telah dilunasi oleh tergugat melalui transfer kepada istri penggugat.

Tentang hutang yang belum dilunasi oleh tergugat kepada penggugat hal ini dikarenakan para tergugat diharuskan menandatangani sebuah akta di hadapan notaris Arif Budiyanto, SH tanpa terlebih dahulu diberi kesempatan kepada tergugat untuk mempelajari isi akta tersebut, sehingga hal ini kemudian memberatkan para tergugat dalam melakukan kesepakatan. Selain itu keterangan saksi menyebutkan kalau pada saat di Notaris 11 Juni 2012 tergugat minta tambahan pinjaman yang semula Rp. 4.000.000.000,- menjadi Rp. 5.000.000.000,- kepada penggugat, permintaan tersebut kemudian dikabulkan oleh penggugat dengan syarat perjanjiannya bukan disebut sebagai hutang piutang karena penggugat malu akan disebut sebagai rentenir nantinya. Dengan alasan tersebut, maka dibuatlah akta perjanjian ikatan jual beli 3 bidan tanah para tergugat dengan menitipkan sertipikat ke tiga bidang tanah tersebut pada notaris Arif Budiyanto, $\mathrm{SH}$.

Gugatan tersebut kemudian ditolak seluruhnya oleh majelis hakim dengan berangkat dari uraian fakta-fakta persidangan yang dicantumkan dalam pertimbangan hukumnya, yaitu sesaat setelah penggugat menandatangani perjanjian ikatan jual beli tersebut, penggugat kemudian menyerahkan cek senilai 
Rp. 5.000.000.000,- kepada para tergugat, bukan senilai Rp. 5.500.000.000,sebagaimana yang disebutkan dalam perjanjian ikatan jual beli. Majelis hakim memandang adanya satu bentuk kesengajaan hubungan hukum antara tergugat dengan penggugat yang secara formal perjanjian tersebut dalam bentuk ikatan jual beli namun dalam pelaksanaanya hubungan hukum antara penggugat dengan tergugat dalam bentuk hutang piutang.

Dalam pandangan majelis hakim, terdapat cacat kehendak dalam perjanjian ini, yaitu penyalahgunaan keadaan yang disebabkan adanya keunggulan ekonomis pada pihak penggugat, sehingga karena dalam keadaan terdesak maka tergugat menyepakati perjanjian ikatan jual beli, bukan perjanjian hutang piutang. Dengan demikian antara kehendak/maksud dengan pelaksanaan terjadi ketidaksingkronan.

Dengan adanya cacat kehendak yang disebabkan penyalahgunaan keadaan karena keunggulan ekonomis, menyebabkan tidak terpenuhinya salah satu syarat sahnya perjanjian sebagaimana diatur dalam Pasal 1320 KUH Perdata yaitu sepakat mereka yang mengikatkan dirinya. Dengan demikian majelis hakim menjatuhkan putusan yaitu menolak seluruh gugatan pengugat.

\section{Putusan Pengadilan Negeri Jakarta Pusat}

Pengadilan Negeri Jakarta menjatuhkan putusan perkara perdata antara Isyuliani Tris Ekowati selaku Penggugat dengan Martina Napitupulu selaku Tergugat dalam nomor Perkara 425/Pdt.G/2011/PN.JKT.PST. Kasus ini berawal ketika penggugat membuat perjanjian pengakuan hutang dengan tergugat sebesar Rp. 65.000.000,- pada 12 Desember 1996 di hadapan notaris Chufran Hamal dengan nomor 46, dengan jaminan dan kuasa untuk membebankan hak tanggungan dan kuasa untuk menjual (sertipikat hak milik No. 455).

Dalam perjanjian tersebut, disepakati tentang pelunasan hutang setelah 4 bulan terjadinya perjanjian pengakuan hutang tersebut, tepatnya 12 April 1997. Namun dalam perjalanannya ternyata usaha suami penggugat menjadi bangkrut dan kemudian membuat suami penggugat stres yang menyebabkan meninggal dunia. 
Perjanjian pengakuan utang itu juga disepakati oleh kedua belah pihak untuk tidak mencantumkan bunga, namun secara lisan disepakati jasa 5\% serta denda Rp. 50.000 per hari jika ada keterlambatan dari jatuh tempo pelunasan hutang tersebut yang kemudian semuanya telah dibayar oleh tergugat beserta pinjaman pokoknya. Penggugat tetap beritikad baik dengan untuk melakukan pembayaran secara cicil dengan rincian sebagai berikut; Januari 1997: Rp. 4.000.000,-; 7 Januari-Desember 1998: Rp. 27.300.000,- ; 1 Februari 1999 - 22 Desember 2000: Rp. 46.732.000,-; 28 Januari 2000 - 23 Desember 2000: Rp. 125.716.000.-; 16 Januari 2001 - 31 Desember 2001: Rp. 26.861.000,-; dan 8 Januari 2001 - Juli 2002: Rp. 5.700.000,-

Dengan rincian tersebut penggugat merasa telah melunasi seluruh hutangnya beserta jasa pinjamannya, namun kemudian tergugat tidak mau mengembalikan jaminan sertipikat milik pengugat, bahkan menurut penggugat ada paksaan untuk menandatangani surat pengakuan hutang sebesar Rp. 950.000.000,-. Sementara tergugat menyatakan bahwa jumlah hutang yang dilunasi oleh penggugat bukan sebesar Rp. 297.609.000,- namun baru hanya sebesar Rp. 130.000.000,- hal ini kemudian menjadi alasan tergugat masih menahan sertipikat milik penggugat.

Lebih lanjut terggugat menyatakan jumlah hutang penggugat menjadi Rp. 82.500.000,- karena ditambah dengan hutang suami penggugat sebesar Rp. 17.500.000,- yang dipinjam pada 28 Desember 1996. Dengan demikian terggugat telah menggabungkan jumlah hutang penggugat dengan jumlah hutang suaminya yang kemudian dikenakan jasa $5 \%$ dari keseluruhan jumlah hutang penggugat dan suaminya.

Melalui duduk perkara tersebut, majelis hakim kemudian memberikan pertimbangan hukum, yaitu:

a. Dari gugatan penggugat tidak ada menyinggung tentang gugatan terhadap hutang suami yang sebesar Rp. 17.500.000,- yang kemudian majelis hakim memandang bahwa tidak ada persoalan antara penggugat dan tergugat terhadap hutang suami tersebut dalam gugatannya.

b. Apabila kemudian dihitung dengan bunga $5 \%$ dalam kurun waktu 12 April 1997 s/d Desember 2002 maka bunga yang harus dibayar penggugat adalah 68 bulan X 5\% X Rp. $65.000 .000=221.000 .000$ ditambah hutang pokok Rp. $65.000 .000=$ Rp. 286.000.000, sehingga pembayaran yang dilakukan penggugat kepada tergugat telah melebihi dari jumlah seharusnya.

c. Oleh karena Sertipikat Hak Milik telah diserahkan kepada penggugat yang terlihat pada saat ditunjukkannya penggugat sertipikat asli di depan 
persidangan, sehingga dimulai dari jatuh temponya hutang penggugat maka sudah seharusnya tergugat melakukan gugatan wanprestasi pada waktu itu juga, namun tergugat justru membiarkan hutang penggugat berlarut-larut tanpa batas waktu yang juga mengakibatkan bertambahnya jumlah bunga.

d. Setelah melihat bukti-bukti atas dalil sangkalan yang disediakan oleh tergugat tentang beberapa surat pernyataan ketidak sanggupan lagi membayar hutang dengan rincian:

1. Tanggal 1 Desember 1998 penggugat menyatakan tidak sanggup lagi membayar pinjaman sebesar Rp. 152.363.770,-

2. Mei 1999 penggugat menyatakan tidak sanggup lagi membayar pinjamannya sebesar Rp.190.454.712,-

3. 30 April 2000 penggugat menyatakan tidak sanggup membayar pinjamannya sebesar Rp. 266.466.000,-

4. 30 September 2000 penggugat menyatakan tidak sanggup lagi membayar pinjamannya sebesar Rp. 321.000.000,-

5. 30 Juni 2001, penggugat menyatakan tidak sanggup lagi membayar pinjamannya sebesar Rp. 405.000.000,- dan seterusnya sampai tanggal 30 Januari 2002 dengan hutang yang semakin tinggi.

e. Jika melihat loncatan hutang penggugat menurut tergugat yang sangat tinggi bahkan melewati batas 5\%, maka majelis hakim menyimpulkan terjadi suatu penyalahgunaan keadaan dalam pengakuan hutang tersebut.

f. Majelis hakim juga mempertimbangkan maksud awal tergugat memberikan pinjaman kepada tergugat untuk membantu, namun kemudian memberikan bunga $5 \%$ dalam jangka waktu 4 bulan yang pada dasarnya sudah melebihi batas bunga bank menurut yurisprudensi yaitu sebesar $6 \%$, maka patut dipertanyakan lagi maksud tergugat memberi pinjaman kepada penggugat.

g. Keadaan penggugat yang hanya sebagai seorang Ibu Rumah Tangga yang telah meninggal suaminya sementara keadaan tergugat yang memiliki dana atau uang yang lebih menggambarkan adanya kedudukan yang tidak seimbang secara ekonomi antara tergugat dengan penggugat, dimana pihak tergugat yang memiliki ekonomi kuat mampu memberikan pinjaman dan pihak penggugat yang memiliki ekonomi rendah, yang demikian majelis hakim menduga tergugat memanfaat kondisi keadaan ekonomi penggugat.

Berdasarkan pertimbangan hukum tersebut, majelis hakim kemudian menjatuhkan putusan sebagai berikut:

a. Mengabulkan gugatan penggugat untuk sebahagian;

b. Menyatakan tergugat telah melakukan perbuatan melawan hukum;

c. Menyatakan tergugat telah melakukan itikad tidak baik terhadap penggugat;

d. Menyatakan penggugat telah melakukan itikad baik yaitu dengan membayar pinjaman pokok dan bunga dan bahkan sudah melebihi; 
e. Menyatakan pinjaman pokok dan bunga pinjaman penggugat sudah melebihi dari pembayaran kewajiban pinjaman dan tidak sesuai dengan sistim peraturan yang berlaku di Lembaga (bank) resmi;

f. Menyatakan Akta Pengakuan Hutang No. 46 tanggal 12 Desember 1996, yang dilakukan dan dibuat di hadapan Notaris Chufran Hamal, SH adalah batal, gugur dan tidak mempunyai kekuatan hukum;

g. Menghukum tergugat untuk mengembalikan Sertifikat Hak Milik No. 455 seluas $2.430 \mathrm{~m} 2$ atas nama penggugat kepada penggugat sekaligus;

h. Menghukum tergugat untuk membayar uang paksa (dwangsom) sebesar Rp. 1.000.000,- (satu juta rupiah) per hari untuk tiap-tiap keterlambatan tidak melaksanakan putusan perkara ini;

i. Menolak gugatan penggugat untuk selebihnya.

\section{Putusan Mahkamah Agung}

Para pihak yang berperkara dalam putusan Putusan Mahkamah Agung Kasus Nomor 2054 K/Pdt/2014 adalah Rusnadi Wijaya sebagai Penggugat / Pembanding / Pemohon Kasasi dengan Norhasanah sebagai Tergugat / Terbanding / Termohon Kasasi. Kasus ini berawal dari sebuah kesepakatan perjanjian hutang antara Penggugat / Pembanding / Pemohon Kasasi dan Tergugat / Terbanding / Termohon Kasasi sebesar Rp. 50.000.000,- yang dituangkan dalam Akta Perjanjian Hutang dengan jaminan Nomor 9, pada 8 Maret 2005 yang dibuat di hadapan Notaris Lukman Hakim Gusti, S.H.

Tergugat/Terbanding/Termohon Kasasi (Norhasanah) menjaminkan seluruh harta kekayaannya yaitu sebidang tanah Sertipikat Hak Milik Nomor 439/Desa Tenggir, seluas $350 \mathrm{~m}^{2}$, yang kemudian jaminan tersebut dibuatkan akta Pemberian Hak Tanggungan Nomor 113/HT/PJ/2005, 8 Maret 2005 yang selanjutnya terbit Sertipikat Hak Tanggungan nomor 208/2005.

Menurut Rusnadi Wijaya jangka waktu perjanjian hutan disepakati selama 1 tahun, sejak 8 Maret 2005 sampai 8 Maret 2006, dan dibayarkan secara sekaligus ketika sudah jatuh tempo. Namun sampai pada jatuh tempo, Norhasanah ternyata tidak mampu melunasi hutangnya yang menimbulkan wanprestasi pada perjanjian yang telah disepakati kedua belah pihak. Menurut Norhasanah, jumlah uang yang diterima dari Rusnadi Wijaya pada saat terjadi kesepakatan sebesar Rp. 25.000.000,namun karena pada waktu itu Norhasanah terlilit hutang lain akhirnya dalam kondisi tersebut dia terpaksa menandatangani akta yang di dalamnya tertulis 
jumlah pinjaman sebesar Rp. 50.000.000,- meskipun yang diterima hanya separuhnya.

Menurut Norhasanah, jumlah hutang sebesar Rp. 25.000.000,- tersebut disepakati pelunasan dengan cara tiga kali pembayaran, yakni: pembayaran pertama Rp. 7.000.000,-; pembayaran kedua Rp. 12.000.000,-; pembayaran ketiga Rp. 6.000.000,-. Norhasanah sebenarnya telah melunasi hutangnya sebesar Rp. 10.000.000,-, sehingga sisa hutang tergugat tinggal Rp. 15.000.000,--

Rusnadi Wijaya kemudian mengajukan kasasi setelah sebelumnya dalam Pengadilan Negeri dan Pengadilan Tinggi Negeri merasa tidak puas dengan putusan yang dijatuhkan. Mahkamah Agung kemudian menyatakan bahwa tidak terdapat kekhilafan hakim serta judex facti (Pengadilan Tinggi dan Pengadilan Negeri) tidak salah menerapkan hukum dengan pertimbangan sebagai berikut:

a. Penggugat dapat membuktikan dalil gugatan tentang adanya hutang piutang berdasar perjanjian antara penggugat dengan tergugat yang kemudian diketahui nilainya sebesar Rp. 25.000.000,-, namun hingga gugatan ini diajukan baru dibayar sebesar Rp. 5.000.000,- sehingga tergugat masih mempunyai hutang sebesar Rp. 20.000.000,- kepada penggugat;

b. Tentang adanya perjanjian yang dibuat setelah adanya hutang piutang tersebut, dengan maksud agar hutang tersebut dapat dibayarkan, dengan mengingat azas keadilan, dikarenakan perjanjian dibuat pada saat debitur dalam keadaan tertekan, perjanjian tersebut memberatkan pihak tergugat, dan terjadi penyalahgunaan keadaan sehingga sewajarnya dinyatakan cacat yuridis dan tidak mempunyai kekuatan hukum;

c. Berdasarkan pertimbangan di atas, ternyata putusan judex facti/Pengadilan Tinggi Surabaya dalam perkara ini tidak bertentangan dengan hukum dan/atau undang-undang, maka permohonan kasasi yang diajukan oleh Pemohon Kasasi Rusnadi Wijaya tersebut, harus ditolak.

Dengan demikian melalui pertimbangan hukum tersebut, Mahkamah Agung menolak permohonan kasasi dari Pemohon Kasasi Rusnadi Wijaya tersebut. Putusan-putusan di atas menyebutkan adanya penyalahgunaan keadaan dalam perjanjian antara kedua belah pihak. Penentuan penyalahgunaan keadaan ini dapat dilihat melalui pertimbangan para majelis hakim. Oleh karena prihal penyalahgunaan keadaan ini berangkat dari doktrin yurisprudensi, maka perlu ditentukan sebuah tolok ukur penyalahgunaan keadaan yang digunakan oleh hakim dalam menjatuhkan putusannya terhadap perkara di atas. 
Hakim dalam mengadili suatu perkara, pertama-tama harus mengkonstatasi benar tidaknya peristiwa yang diajukan kepadanya. Setelah berhasil mengkonstatasi peristiwanya, hakim kemudian harus mengkualifikasi peristiwa tersebut. Setelah itu hakim harus menentukan hukum apa yang akan digunakan untuk menyelesaikan sengketa yang bersangkutan. Di sini kemudian hakim harus menemukan hukum. Hakim di Indonesia dalam menemukan hukum ini dapat merujuk kepada beberapa sumber hukum peraturan perundang-undangan dan yurisprudensi, namun hakim tidak terikat pada yurisprudensi atau putusan hakim yang terdahulu dalam kasus yang sebangun. Dalam hal ini pengadilan di Indonesia tidak menganut asas the binding force of precedent atau stare decisis. Dampak negatif tidak dianutnya asas ini adalah dimungkinkannya putusan pengadilan menjadi tidak konsisten dan dapat menimbulkan ketidakpastian hukum. Di sisi lain, tidak dianutnya asas ini ternyata juga menimbulkan dampak positif yaitu hakim atau pengadilan berpeluang membangun hukum yudisial baru yang dapat mengikuti perkembangan masyarakat dalam putusan-putusannya. ${ }^{11}$ Sebab terdapat beberapa kasus nampak sebangun namun kadang berbeda jika ditelusuri lebih jauh.

Eksplorasi penemuan hukum bagi hakim seperti yang dijelaskan di atas nampak pada beberapa putusan yang sudah dipaparkan di atas. Hakim sudah menerapkan doktrin penyalahgunaan keadaan dalam menjatuhkan putusannya tersebut. Dengan penerapan doktrin penyalahgunaan ini, dapat ditarik beberapa tolok ukur yang digunakan oleh hakim dalam menentukan adanya penyalahgunaan keadaan ini.

1) Tolok ukur moral yang meliputi kepatutan dan keadilan. Kepatutan dan keadilan digunakan oleh hakim sebagai tolok ukur dalam menentukan penyalahgunaan keadaan keadaan kedua belah pihak, hal ini nampak dalam pertimbangan hakim yang melihat adana keunggulan ekonomis dan psikologis yang dimiliki kreditor sehingga mengakibatkan posisi tawar yang tidak seimbang antara kedua pihak.

2) Tolok ukur itikad baik. Hakim menjadikan tolok ukur itikad tidak baik sebagai bentuk awal adanya penyalahgunaan keadaan, hal ini terlihat ketika hakim mempertimbangkan maksud kreditor memberi pinjaman uang kepada debitor semata-mata hanya ingin membantu namun pada kenyataanya berbeda.

11 Ridwan Khairandy, Itikad Baik dalam Kebebasan Berkontrak, Program Pascasarjana, Fakultas Hukum Universitas Indonesia, Jakarta, 2004, hlm. 265. 
3) Tolok ukur keuntungan. Tolok ukur keuntungan yang digunakan oleh hakim juga berkaitan dengan itikad baik, yaitu saat seorang kreditor memberikan pinjaman dengan maksud membantu namun ternyata hanya ingin meraup keuntungan dengan manaikkan bunga pinjaman dalam waktu yang singkat, yang kemudian ini bertentangan dengan kepatutan dan undang-undang. ${ }^{12}$

Niewenhuis yang menyebutkan tentang dua aspek penting untuk mengetahui sifat serta luasnya hak dan kewajiban dari hubungan kontraktual, yaitu: ${ }^{13}$

a. Interpretasi (penafsiran; uitleg) terhadap sifat serta luasnya hak dan kewajiban kontraktual,

b. Faktor-faktor yang berpengaruh terhadap sifat serta luasnya hak dan kewajiban kontraktual, meliputi:

1) Faktor otonom (terkait daya mengikatnya kontrak)

2) Faktor heteronom (faktor-faktor yang berasal dari luar para pihak), terdiri dari: undang-undang, kebiasaan (gebruik), syarat yang biasa diperjanjikan (bestandig gebruikelijk beding), kepatutan (billijkheid), dan keadilan.

Dalam permasalahan ini hakim sudah mempertimbangkan faktor heteronom dalam menentukan adanya penyalahgunaan dengan melihat pertimbanganya dari aspek kepatutan dan keadilan pihak yang lemah.

\section{Akibat Hukum Perjanjian Pinjam Meminjam Uang oleh Rentenir}

Dalam kondisi terdesak seorang debitur tidak lagi memikirkan isi perjanjian atau syarat perjanjian yang disampaikan oleh rentenir, melainkan fokus pada tujuannya yaitu keinginannya untuk memiliki uang agar kebutuhan yang terdesak bisa terpenuhi, misal memenuhi kebutuhan primer atau bahkan terkadang untuk menutupi hutang yang lainnya karena desakan dari kreditur yang lain.

Perjanjian yang demikian menjadi jalan debitur (rentenir) meraup keuntungan yang sebesar-besarnya yaitu dengan meninggikan bunga yang sangat besar dalam waktur yang relatif singkat. Dalam kondisi tersebut, seorang debitur (rentenir) menggunakan keunggulan ekonominya dalam menentukan bunga sesuai kemauannya sendiri, sehingga bunga yang ditentukannya pun sangat besar,

\footnotetext{
12 Undang-undang yang dimaksud yaitu tentang peraturan jumlah bunga 6\% per tahun.

13 Siti Malikhatun Badriyah, Sistem Penemuan Hukum dalam Masyarakat Prismatik, Sinar Grafika, Jakarta, 2016,
} hlm. 123. 
bahkan melebihi dari bunga moratoir (bunga yang diatur dalam undang-undang), meskipun sebenarnya tidak dilarang penentuan jumlah bunga ini atas dasar kebebasan berkontrak (asas konsensualisme).

Terjadinya penyalahgunaan keadaan dalam perjanjian ini dapat dilihat dari dua unsur, yaitu pertama: pihak yang kuat dapat memaksakan kehendaknya kepada pihak yang lemah, sehingga pihak yang lemah mengikuti saja syarat-syarat kontrak yang diajukan kepadanya, kedua: kekuasaan tersebut digunakan untuk memaksakan kehendak sehingga membawa keuntungan kepadanya. Akibatnya, kontrak tersebut menjadi tidak masuk akal dan bertentangan dengan aturan-aturan yang adil. ${ }^{14}$ Dua unsur ini terdapat pada perjanjian pinjam meminjam uang atau utang piutang yang dilakukan oleh rentenir (kreditur) dengan debiturnya, yaitu seorang rentenir yang memiliki posisi yang kuat ekonominya memaksakan kehendaknya kepada debiturnya yang berada pada posisi ekonomi lemah, dan kemudian debitur secara terpaksa juga harus mengikutinya. Begitu juga dalam hal keuntungan yang didapat oleh rentenir dalam jumlah besar yang bahkan dalam pandangan akal sehat sangat tidak patut seperti yang terjadi pada kasus putusan di atas.

Penentuan bunga dalam perjanjian memang pada dasarnya tidak dilarang, namun tetap dibatasi oleh aspek moral dengan melihat asas keadilan dan kepatutan seperti yang dijelasakan sebelumnya. Manakala penentuan bunga itu jauh dari kepatutan dan keadilan maka dapat dinyatakan debitur (rentenir) menyalahgunakan keadaan dalam keunggulan ekonomi yang dimilikinya.

\section{Perjanjian Pinjam Meminjam Uang Oleh Rentenir Dapat Dibatalkan}

Perjanjian utang piutang antara rentenir dengan debiturnya dapat dipastikan terjadi penyalahgunaan keadaan berdasarkan pembahasan di atas, lalu kemudian bagaimana akibat hukum dari perjanjian utang piutang oleh rentenir yang mengandung penyalahgunaan keadaan. Sebelum membahas hal tersebut, perlu diawali dengan melihat terlebih dahulu posisi penyalahgunaan keadaan dalam hukum perjanjian.

${ }^{14}$ Sutan Remy Sjahdeini, Kebebasan Berkontrak dan Perlindungan yang Seimbang bagi Para Pihak dalam Perjanjian Kredit Bank di Indonesia, Institut Bankir Indonesia, Jakara, 1993, hlm. 207. 
Terbentuknya ajaran tentang penyalahgunaan keadaan adalah disebabkan belum adanya (waktu itu) ketentuan Burgerlijk Wetboek (Belanda) yang mengatur hal itu. Salah satu pembahasan adalah menyangkut penerapan Pasal 1320 KUH Perdata tentang syarat-syarat sahnya perjanjian (kesepakatan, kecakapan, pokok persoalan, bukan sebab yang terlarang), apakah tepat menggolongkan penyalahgunaan keadaan itu ke dalam sebab (causa) yang tidak dibolehkan (syarat sah yang keempat) atau tidak. ${ }^{15}$

Van Dunne mengajukan pendapatnya, bahwa tidaklah tepat menyatakan perjanjian yang terjadi di bawah pengaruh penyalahgunaan bertentangan dengan kebiasaan yang baik. Penyalahgunaan keadaan itu berhubungan dengan terjadinya kontrak. Bahwa suatu perjanjian terjadi dalam keadaan-keadaan tertentu tidak mempunyai pengaruh atas dibolehkan tidaknya sebab perjanjian itu. ${ }^{16}$

Setiawan juga mengajukan pendapat Cohen, yang menyatakan bahwa tidak tepat menggolongkan sebagai kausa yang tidak halal (ongeoorloofde oorzaak, Pasal 1320 sub ke empat KUH Perdata). Kausa yang tidak halal memiliki ciri yang sangat berbeda, karena tidak ada kaitannya dengan kehendak yang cacat. Meskipun pihak yang bersangkutan tidak mendalilkannya sebagai alasan untuk menyatakan batalnya perjanjian namun dalam hal kausa tidak halal, hakim secara ex officio wajib mempertimbangkannya. Berbeda halnya dengan kehendak yang cacat (wilsgebrek): pernyataan batal atau pembatalan perjanjian hanya akan diperiksa oleh hakim kalau dilakukan oleh yang bersangkutan. ${ }^{17}$

Menggolongkan penyalahgunaan keadaan sebagai salah satu bentuk cacat kehendak, lebih sesuai dengan kebutuhan konstruksi hukum dalam hal seseorang yang dirugikan menuntut pembatalan perjanjian. Gugatan atas dasar penyalahgunaan keadaan terjadi dengan suatu tujuan tertentu. Penggugat harus mendalilkan bahwa perjanjian itu sebenarnya tidak ia kehendaki atau bahwa perjanjian itu tidak ia kehendaki dalam bentuknya yang demikian. ${ }^{18}$

15 H.P. Panggabean, Penyalahgunaan Keadaan sebagai Alasan (Baru) untuk Pembatalan Perjanjian, Liberty, Yogyakarta, 2010, hlm. 49.

${ }^{16}$ Ibid., hlm. 50

${ }^{17}$ Ibid., hlm. 51.

18 Ibid. 
Dalam perkembangan selanjutnya, penyalahgunaan keadaan tidak dimasukkan lagi ke dalam kausa yang tidak halal melainkan dimasukkan ke dalam kategori cacat kehendak. Penyalahgunaan dikategorikan sebagai kehendak yang cacat karena lebih sesuai dengan isi dan hakikat penyalahgunaan keadaan itu sendiri, ia tidak berhubungan dengan syarat-syarat objektif perjanjian, melainkan mempengaruhi syarat-syarat subjektif. ${ }^{19}$ Apabila syarat subjektif tidak terpenuhi maka akibatnya perjanjian tersebut dapat dibatalkan (vernietigbaar/voidable), sedangkan apabila syarat objektif tidak terpenuhi, maka berakibat perjanjian tersebut batal demi hukum (nietigbaar/null and void). ${ }^{20}$

Penyalahgunaan keadaan dapat mengakibatkan suatu perjanjian tidak mempunyai kekuatan hukum, kalau perjanjian itu diadakan dengan bertolak dari suatu penyebab yang bertentangan dengan moralitas yang baik dan penggunaan keadaan yang mengakibatkan pihak lawan tidak dapat mengambil putusan yang bersifat independen. ${ }^{21}$

Berdasarkan dari uraian di atas, maka penyalahgunaan keadaan merupakan bentuk cacat syarat subjektif dari sahnya perjanjian (cacat kehendak), dengan demikian juga akibat hukum dari perjanjian pinjam meminjam uang atau hutang piutang oleh rentenir dengan debiturnya yang terdapat penyalahgunaan keadaan di dalamnya dapat dibatalkan dengan mengajukan permohonan pembatalan perjanjian oleh pihak yang memiliki posisi lemah. Namun jika sepanjang para pihak tidak ada yang merasa rugi dalam perjanjian tersebut, maka perjanjian itu tetap sah dan mengikat kedua belah pihak meskipun nampak terdapat cacat kehendak (yaitu penyalahgunaan keadaan) di dalam perjanjian tersebut.

Suatu perjanjian yang cacat kehendak dari pihak-pihak yang membuatnya tidak serta merta membawa kerugian bagi para pihak yang bersangkutan. Karena ada kemungkinan bahwa perjanjian yang ditutup dalam keadaan demikian masih dapat dianggap layak. Oleh karena itu, tindakan hukum yang cacat kehendak

${ }^{19}$ Ridwan Kharandy, Hukum Kontrak Indonesia dalam Perspektif Perbandingan (Bagian Pertama), Op. Cit., hlm 231.

${ }^{20}$ Siti Malikhatun Badriyah, Sistem Penemuan Hukum dalam Masyarakat Prismatik, Op. Cit., hlm 98.

${ }^{21}$ Ridwan Khairandy, Hukum Kontrak Indonesia dalam Perspektif Perbandingan (Bagian Pertama), Op. Cit., hlm 232. 
dinyatakan dapat dibatalkan dan berdasarkan asas keseimbangan pihak yang dirugikan dapat mengajukan tuntutan pembatalan tersebut. ${ }^{22}$

Jadi sebenarnya perjanjian pinjam-meminjam uang yang terdapat penyalahgunaan keadaan di dalamnya tidaklah berakibat apa-apa (artinya tetap berlaku ketentuan-ketentuan perjanjian secara umumnya bagi para pihak) sepanjang tidak melakukan permohonan pembatalan perjanjian pada pengadilan.

Di samping itu juga, batalnya suatu perjanjian karena penyalahgunaan keadaan sama sekali tidak mutlak adanya satu taraf tertentu atau satu bentuk tertentu dari hal yang merugikan itu. Dirugikannya salah satu dari pihak-pihak hanya merupakan salah satu dari faktor-faktor yang di samping semua keteranganketerangan lain seperti sifat dari keadaan-keadaan yang digunakan cara berlangsungnya penggunaan itu dan hubungan antara pihak-pihak menentukan apakah perjanjian itu bertolak satu sebab yang bertentangan dengan moralitas yang baik. ${ }^{23}$

\section{Penutup}

Berdasarkan dari hasil penelitian pada pembahasan sebelumnya, maka dapat disimpulkan bahwa : Pertama, tolok ukur yang digunakan oleh hakim dalam menentukan adanya penyalahgunaan keadaan dalam perjanjian pinjam meminjam uang ada 3, yaitu: moral (kepatutan dan keadilan), itikad baik, dan keuntungan.

Tolok ukur pertama, yaitu tolok ukur moral digunakan oleh hakim terlihat ketika melihat posisi yang tidak seimbang dalam perjanjian pinjam meminjam uang antara debitor dengan kreditor, dimana kreditor memiliki keunggulan ekonomis dan psikologis atas debitor yang kemudian disalahgunakan. Tolok ukur kedua, yaitu tolok ukur itikad baik juga digunakan oleh hakim dalam menentukan adanya penyalahgunaan keadaan dalam perjanjian pinjam meminjam uang, hal ini terlihat ketika hakim mempertimbangkan maksud awal seorang kreditor memberi pinjaman sekedar untuk menolong, namun pada kenyataannya ingin meraup hlm. 101.

${ }^{22}$ Herlien Budiono, Asas Keseimbangan bagi Hukum Perjanjian Indonesia, Citra Aditya Bakti, Bandung, 2015, ${ }^{23}$ Ibid., hlm. 232. 
keuntungan yang besar. Tolok ukur ketiga yaitu tolok ukur keuntungan, terlihat digunakan oleh hakim dalam putusannya ketika seorang kreditor menaikkan bunga dalam waktu yang relatif singkat dengan maksud meraup keuntungan yang banyak tersebut.

Kedua, penyalahgunaan keadaan digolongkan sebagai syarat subjekif sahnya perjanjian karena berkaitan dengan kehendak para pihak. Dengan demikian, akibat hukum dari penyalahgunaan yang terdapat dalam perjanjian pinjam meminjam uang atau utang piutang antara rentenir dengan debiturnya dapat dimohonkan pembatalan kepada pengadilan. Namun, apabila pihak yang lemah tidak mengajukan pembatalan, maka perjanjian tersebut tetap berlaku dan mengikat para pihak.

Dalam penelitian ini ada beberapa saran yang perlu diperhatikan kedepannya yaitu, kepada para akademisi hukum agar kiranya terus mengkaji mengembangkan konsep penyalahgunaan keadaan ini agar dapat lebih diterapkan dengan efektif. Begitu juga kepada lembaga penegak hukum untuk lebih progresif dalam menangani masyarakat yang terjebak dalam perjanjian yang mengandung unsur penyalahgunaan keadaan serta membantu memberantas rentenir karena bertentangan dengan kepatutan dan norma agama. Serta seluruh masyarakat agar kiranya untuk semaksimal mungkin menghindari dan tidak terpengaruh melakukan hutang piutang dengan rentenir agar tidak terjebak dalam permasalahan yang berlarut-larut.

\section{Daftar Pustaka}

\section{Buku}

Badriyah, Siti Malikhatun, Sistem Penemuan Hukum dalam Masyarakat Prismatik, Sinar Grafika, Jakarta, 2016.

Budiono, Herlien, Asas Keseimbangan bagi Hukum Perjanjian Indonesia, Citra Aditya Bakti, Bandung, 2015.

Miru, Ahmadi, dan Sakka Pati, Hukum Perikatan Penjelasan Makna Pasal 1233 sampai 1456 BW, Rajawali Press, Jakarta, 2012.

Muljadi, Kartini dan Gunawan Widjaja, Perikatan yang Lahir dari Perjanjian, Rajawali Press, Jakarta, 2014.

Panggabean, H.P., Penyalahgunaan Keadaan sebagai Alasan (Baru) untuk Pembatalan Perjanjian, Liberty, Yogyakarta, 2010. 
Ridwan, Khairandy, Itikad Baik dalam Kebebasan Berkontrak, Program Pascasarjana Fakultas Hukum Universitas Indonesia, Jakarta, 2003.

,Hukum Kontrak Indonesia dalam Perspektif Perbandingan (Bagian Pertama), FH UII Pres, Yogyakarta, 2014.

Satrio, J., Hukum Perikatan Pada Umumnya, Penerbit Alumni, Bandung, 1993.

Sjahdeini, Sutan Remy, Kebebasan Berkontrak dan Perlindungan yang Seimbang bagi Para Pihak dalam Perjanjian Kredit Bank di Indonesia, Institut Bankir Indonesia, Jakara, 1993.

Syaifuddin, Muhammad, Hukum Kontrak Memahami Kontrak dalam Perspektif Filsafat, Teori, Dogmatik, dan Praktik Hukum, CV Mandar Maju, Bandung, 2012.

\section{Jurnal, Tesis, Skripsi}

Ali Hamka, Aldrin dan Tyas Danarti, “Eksistensi Bank Thithil dalam Kegiatan Pasar Tradisional (Studi Kasus di Pasar Kota Batu)," Journal of Indonesian Applied Economics, Edisi 1 Vol. 4. 2010.

Korwadi Siboro, Ilas, "Rentenir (Analisis terhadap Fungsi Pinjaman Berbunga dalam Masyarakat Rokan Hilir Kecamatan Bagan Sinembah Desa Bagan Batu)", Jom Fisip, Edisi No. Vol. 2, 2015.

Putra, Fani Martiawan Kumara, "Paksaan Ekonomi dan Penyalahgunaan Keadaan sebagai Bentuk Cacat Kehendak dalam Perkembangan Hukum Kontrak", Jurnal Yuridika, Vol. 30 No. 2, Mei-Agustus 2015.

Sirait, Lisken, “Fenomena Rentenir di Pasar Bintan Center (Studi Pedagang Kecil di Pasar Intan Center)," Skripsi, Tanjungpinang: Universitas Maritim Raja Ali Haji FISIPOL, 2015.

Syafrini, Delmira, "Nelayan vs Rentenir Studi Ketergantungan Nelayan terhadap Rentenir pada Masyarakat Pesisir", Jurnal Ilmu Sosial Mamangan, Edisi No. 2, Vol. I. 2014. 